\title{
Fertilizer Use Pattern on Major Crops Grown in Karnal District of Haryana, India
}

\author{
Vijay Kumar $^{1^{*}}$, Ishwar Dutt ${ }^{2}$ and Reetu Devi ${ }^{3}$ \\ ${ }^{1}$ Department of Economic \& Statistical Analysis, Govt. of Haryana, India \\ ${ }^{2}$ Department of Agri. \& Farmer's Welfare, Govt. of Haryana, India \\ ${ }^{3}$ I.C. Collage of Home Science, CCS HAU, Hisar, Haryana, India \\ *Corresponding author
}

\begin{abstract}
A B S T R A C T
Keywords

Fertilizer expenditure, Pattern of fertilizer use,

Marginal value

productivity,

Determinants of fertilizer use

Article Info

Accepted:

15 September 2018

Available Online:

10 October 2018

The average quantity of fertilizer use per hectare of the cropped area in 2015-16 was found as $206 \mathrm{~kg}$ for the State as a whole. During the same period, it was $293.95 \mathrm{~kg}$ in Karnal district, which comes out 142 per cent of the State average. In total consumption of NPK the proportions of $\mathrm{N}, \mathrm{P}$ and $\mathrm{K}$ were respectively, 80.29, 17.34 and 2.36 per cent in Karnal district whereas for the State as a whole these were $77,21.5$ and 1.5 per cent respectively. The study revealed that on small farms one hectare in size of holding increased the expenditure on fertilizers by Rs. 1383.20. However, on large holdings the one hectare increase in size of holding resulted in an increase of Rs. 1253.40 on fertilizers expenditure. The percentage of irrigated area on small farms was more as compared with large farms, the expenditure on fertilizer per hectare of net area shown is also more on large farms than the small farms. It was found that the extent of fertilizer consumption is dependent upon mainly on two factors namely area fertilized and the quantity of fertilizers used per hectare. Both of these in turn are dependent upon several factors namely; the economics of fertilizer use and ability of farmers to purchase fertilizers.
\end{abstract}

\section{Introduction}

The use of fertilizer depends largely on the availability of irrigation facilities and availability of working capital with the farmers for acquiring the purchased inputs. As the small farmers have inadequate capital base, the non-available of adequate credit may be a problem in exploiting the production potentials by them. The farmers may also have different attitudes to different crops grown on the farm regarding to application of fertilizer. This may be influenced by the relative profitability of the crops, degree of yield and price risks involved and the personal likings and consumption needs of the farm family.

Thus, institutional, financial and behavioural constraints condition the farmer's decisions concerning his farm practices in general and use of fertilizer in particular. These constraints must be evaluated for the level of their incidence and their impact of fertilizer use at farm level. Such a study is all the more important to keep up our farm production targets. 
The present study was undertaken in the Karnal district of Haryana where the consumption of fertilizers per hectare of cropped area is very high, to examine the pattern and efficiency of fertilizer use in the major crops of the district.

\section{Materials and Methods}

Taking into consideration the both Zonal qualities and very high consumption of fertilizer nutrient per hectare of cropped area, Karnal district of Haryana was selected purposively on the ground that district Karnal having sandy to fine sandy loams and clayey loam, therefore most of the crops are grown in this district unlikely to other districts of Haryana.

\section{Selection of villages}

Stratified Random Sampling was used for selection of sample. District Karnal has been divided into four strata and Two villages were selected randomly from each of the five strata/tehsils namely; Assandh, Gharaunda, Karnal, Indri and Nilokheri, to cover the whole district

\section{Selection of farmers}

A list of farmers was prepared according to their operational holdings and Out of these ten villages a total of 60 farmers 6 from each selected villages was selected for the study.

\section{Source of data}

Both the primary and secondary data was used to fulfill the objectives of the study.

\section{Selection of farmers}

A list of all the farmers in each selected village was prepared with their operational holdings into ascending order and then it was divided into three categories i.e. small (acreage up to $2 \mathrm{ha}$ ), medium (from 3 ha to 10 ha) and large farmers (above $10 \mathrm{ha}$ ). Table 1 shows the number of farmers selected from each village in each class of operational holding.

\section{Analytical techniques}

Production function analysis was carried out to estimate the response of fertilizers on major crops grown on the selected farms under irrigated and conditions. Keeping in view the nature of data collected and objectives of the study, the Cobb-Douglas and quadratic forms of production function has been fitted to estimate the relationship between per hectare output of crops i.e. wheat, paddy, mustard, gram and Sugarcane and quantities of nitrogen and phosphorus applied in producing these crops.

For selecting a particular equation as the "best fit' two empirical criteria were used in this study. One criterion was the magnitude of the coefficient of determination, $\mathrm{R}^{2 \text {, assuming }}$ errors to be normally and independently distributed, with $\mathrm{R}^{2}$ indicating the proportion of variance in the dependent variable accounted for by a particular type of equation, the larger value was taken to indicate the form which was most appropriate for estimates. Other related statistical used as empirical criteria was ' $t$ ' test (the null hypothesis of regression coefficient at zero level). The constant in both the equations was computed and ' $t$ ' test was used to indicated terms. While selecting a particular equation as the 'best fit' both $\mathrm{R}^{2}$ value and ' $\mathrm{t}$ ' test was considered. An equation with a high value of $\mathrm{R}^{2}$ and relatively more number of significant constant terms was ultimately selected as the 'best fit'. On these tests, out of the two functions fitted the following form of quadratic equation was considered as the 'best fit' for estimating the response of fertilizers in different crops. 
$\mathrm{Y}=\mathrm{a}+\mathrm{b}_{1} \mathrm{~N}+\mathrm{b}_{2} \mathrm{P}-\mathrm{b}_{3} \mathrm{~N}^{2}-\mathrm{b}_{4} \mathrm{P}^{2}+\mathrm{b}_{5} \mathrm{NP}(1)$

Where,

$\mathrm{Y}=$ Yield (output) in quintals per hectare

$\mathrm{a}=$ constant (yield in quintals per hectare at zero level of nitrogen and phosphorus)

$\mathrm{N}=$ Nitrogen in $\mathrm{Kg}$ per hectare

$\mathrm{P}=$ Phosphorus in $\mathrm{Kg}$ per hectare; and

$b_{1}, b_{2}, b_{3}, b_{4}$ and $b_{5}$ are the coefficient attached to $\mathrm{N}$ and $\mathrm{P}$ indicating transformation ration of different magnitudes of $\mathrm{N}$ and $\mathrm{P}$.

\section{Marginal Value Productivity}

The marginal value productivities (MVPs) of nitrogen and phosphorus (at their mean levels) was estimated by taking the partial derivative of the production function of the concerned crop and multiplying it with the price of its output (py) ${ }^{1}$.

Thus, MVP of nitrogen was calculated as

$$
\begin{aligned}
& \square \mathrm{Y} \\
& ----=b_{1}-2 b_{3} N+b_{5} P(2) \\
& \square N \\
& \operatorname{MVP}_{N}=\left(b_{1}-2 b_{3} N+b_{5} P\right) P_{y}(3)
\end{aligned}
$$

Similarly, MVP of phosphorus was calculated as-

$$
\begin{aligned}
& \square \mathrm{Y} \\
& \square \mathrm{P} \\
& \mathrm{MVP}_{\mathrm{P}}=\left(\mathrm{b}_{2}-2 \mathrm{~b}_{4} \mathrm{~N}+\mathrm{b}_{5} \mathrm{P}\right) \mathrm{P}_{\mathrm{y}}(5)
\end{aligned}
$$

Regression analysis was done to estimate the contribution of the size of operational holding and irrigated area on the fertilizer use. Other variables like area under high yielding varieties/ commercial crops and the annual income of the farmer were not considered in the analysis because these were found correlated either with the irrigated area or with the size of the holding. Tabular analysis was done to drive some of the results of first and third objectives of the study.

\section{Results and Discussion}

\section{Crop-wise expenditure on fertilizer use}

The crop-wise expenditure on fertilizer use under irrigated conditions on sample farms of different categories in Karnal district has been presented in Tables 2, 3, 4 and 5. Maximum expenditure was incurred in Sugarcane (Rs. 2152/- per acre) which accounted for about 5.37 per cent of the total cost of Sugarcane production.

Sugarcane was followed by Wheat in terms of expenditure on fertilizers (Rs. 1683/-). Paddy is the next important crop in that order where the expenditure on fertilizers was Rs. 1553/-. Though Mustard is also an important crop of the district in kharif season the average expenditure on fertilizer use in this crop was only Rs. 722/- per acre.

Among all the major crops of the district minimum expenditure was in Gram (Rs.460/per acre) which accounted only $6.38 \%$ of the total cost of production of Gram.

\section{Marginal productivity of the fertilizer application for major crops of the district}

As in district Karnal during 2015-16 out of total NPK consumption the share of Nitrogen is $80.29 \%$, Phosphorus $17.34 \%$ and of Potassium is only $2.36 \%$ which is very low as compare to other two, therefore in analysis the MVP of Nitrogen and Phosphorus was calculated. 
Table.1 Number of farmers selected from sample villages

\begin{tabular}{|l|l|l|l|l|l|}
\hline \multirow{2}{*}{ Tehsil } & Villages & Number of farmers selected \\
\hline \multirow{4}{*}{ Assandlh } & Ballah & Small & Medium & Large & Total \\
\hline \multirow{2}{*}{ Gharaunda } & Phaphrana & 3 & 2 & 1 & 6 \\
& Gagsina & 3 & 2 & 1 & 6 \\
\hline Karnal & Rasin & 3 & 2 & 1 & 6 \\
& Shekhpura & 3 & 2 & 1 & 6 \\
\hline Indri & Gheer & 3 & 2 & 1 & 6 \\
& Gharhi Birbal & 3 & 2 & 1 & 6 \\
\hline \multirow{2}{*}{ Nilokheri } & Jainpur sadhaan & 3 & 2 & 1 & 6 \\
\hline \multirow{2}{*}{ Grand Total } & Sagga & 3 & 2 & 1 & 6 \\
\hline & Anjalthali & 3 & 2 & 1 & 6 \\
\hline
\end{tabular}

Table.2 Fertilizer expenditure on sample farms (Small farms) in different crops in Karnal district, 2015-16

\begin{tabular}{|l|r|r|r|r|r|}
\hline Crops & Fertilizer expenditure & Total & $\begin{array}{l}\text { A verage cost } \\
\text { of production }\end{array}$ & $\begin{array}{l}\text { \% of fertilizer } \\
\text { expenditure to } \\
\text { total cost of } \\
\text { production }\end{array}$ \\
\hline & $\mathrm{N}$ & & & & \\
\hline
\end{tabular}

Table.3 Fertilizer expenditure on sample farms (Medium farms) in different crops in Karnal district, 2015-16

\begin{tabular}{|c|c|c|c|c|c|}
\hline \multirow[t]{2}{*}{ Crops } & \multicolumn{2}{|c|}{ Fertilizer expenditure } & \multirow[t]{2}{*}{ Total } & \multirow[t]{2}{*}{$\begin{array}{l}\text { A verage cost } \\
\text { of production }\end{array}$} & \multirow[t]{2}{*}{$\begin{array}{l}\% \text { of fertilizer } \\
\text { expenditure to total } \\
\text { cost of production }\end{array}$} \\
\hline & $\mathrm{N}$ & $\mathrm{P}_{2} \mathrm{O}_{5}$ & & & \\
\hline Wheat & 880 & 805 & 1685 & 11510 & 14.64 \\
\hline Gram & 140 & 320 & 460 & 7208 & 6.38 \\
\hline Mustard & 321 & 402 & 723 & 8760 & 8.25 \\
\hline Paddy & 704 & 805 & 1509 & 17940 & 8.41 \\
\hline Sugarcane & 1310 & 870 & 2180 & 40080 & 5.44 \\
\hline
\end{tabular}


Table.4 Fertilizer expenditure on sample farms (Large farms) in different crops in Karnal district, 2015-16

\begin{tabular}{|c|c|c|c|c|c|}
\hline & & & & & (Rupees per acre) \\
\hline Crops & Fertilizer expen & diture & Total & A verage cost & $\%$ of fertilizer \\
\hline & $\mathrm{N}$ & $\mathrm{P}_{2} \mathrm{O}_{5}$ & & & \\
\hline Wheat & 855 & 805 & 1660 & 12780 & 12.99 \\
\hline Gram & 120 & 300 & 420 & 7640 & 5.50 \\
\hline Mustard & 295 & 402 & 697 & 8910 & 7.82 \\
\hline Paddy & 680 & 805 & 1485 & 18170 & 8.17 \\
\hline Sugarcane & 1200 & 805 & 2005 & 41830 & 4.79 \\
\hline
\end{tabular}

(Figures in parentheses indicate the quantities of fertilizer in terms of nutrients)

Table.5 Existing expenditure on fertilizer on sample farms in Karnal district in 2015-16

\begin{tabular}{|c|c|c|c|c|c|}
\hline & & & & & (Rupees per acre) \\
\hline Crops & Fertilizer expen & diture & Total & A verage cost & $\%$ of fertilizer \\
\hline & $\mathrm{N}$ & $\mathrm{P}_{2} \mathrm{O}_{5}$ & & & \\
\hline Wheat & 878 & 805 & 1683 & 12123 & 13.89 \\
\hline Gram & 137 & 333 & 470 & 7443 & 6.31 \\
\hline Mustard & 320 & 402 & 722 & 8797 & 8.21 \\
\hline Paddy & 703 & 850 & 1553 & 17783 & 8.73 \\
\hline Sugarcane & 1303 & 848 & 2152 & 40103 & 5.37 \\
\hline
\end{tabular}

Table.6 Marginal value productivity of nitrogen and phosphorus in major crop in Karnal district

\begin{tabular}{|l|l|l|}
\hline Crops & Marginal value productivity (Rs.) \\
\hline & Nitrogen & Phosphorus \\
\hline Wheat & 21.3 & 41.6 \\
\hline Gram Irrigated & 32.8 & 46.7 \\
\hline Mustard Irrigated & 23.6 & 32.4 \\
\hline Paddy & 22.9 & $\mathbf{4 5 . 2}$ \\
\hline Sugarcane & $\mathbf{3 4 . 2}$ & $\mathbf{4 7 . 8}$ \\
\hline
\end{tabular}

\section{Crop production functions}

The regression coefficients for all the major crops namely Sugarcane, Paddy, Wheat, Mustard, Gram were worked out. The regression coefficients of Nitrogen and
Phosphorus for all the crops were found positive and significant at 5 per cent probability level under irrigated conditions. The values of the coefficient of multiple determinations (R2) of the estimated production functions were also consistent. 
Marginal value productivity of Nitrogen and Phosphorus

The marginal value productivities (MVPs) of Nitrogen and Phosphorus (at their mean levels) were estimated by taking partial derivative of the production function of the concern crop and multiplying with the price of its output and have been presented in Table 6.

\section{Determinant of fertilizer use}

The regression analysis was carried out to find out the influence of size of holdings and area under irrigation on the total expenditure on fertilizers.

The functions reveal that on small farms one hectare increase in size of holding the expenditure on fertilizers by Rs. 1383.20. However, on large holdings the one hectare increase in size of holding resulted in an increase of Rs. 1253.40 on fertilizer expenditure. The analysis reveals that there is an inverse relationship between the size of holding \& per hectare expenditure on fertilizer. On overall basis it was found that the fertilizer expenditure increased by Rs. 1316.0 with the increase in size of holding by one hectare. The study shows that the percentage of irrigated area in small farms is more as compared with large farms therefore; the expenditure on fertilizer per hectare of net area shown is more on small farms than the large farms.

\section{Acknowledgements}

My special thanks are to Management of Additional Deputy Commissioner, Karnal office and faculty. With all humanity and sincerity, I also express my heartfelt thanks to Dr. U.K. Sharma, Principal DES, Krishi Vigyan Kendra, Bawal, CCS Haryana Agricultural University, Hisar and Dr. O.P.
Sheoran, Associate. Professor, Statistics, Computer Cell, CCS, HAU, Hisar for their precious guidance and support during the course of my studies.

My sincere thanks are due to the Department of Economic and Statistical Analysis and Agricultural Department of Haryana for providing the secondary data used for research purpose.

\section{References}

Afua, B. Banful, Nkanya Ephraim and Oboh Victor. (2010). Constraints to Fertilizer Use in Nigeria. IFPRI Discussion Paper 01010.

Ariga Joshua and Jayne. T.S. (2008). Trends and patterns in Fertilizer use by Smallholder farmers in Kenya, 19972007. Tegemeo Institute of Agricultural Policy and Development. WPS 28/2008. Egerton University, Kenya.

Demeke, Mulat, Kelly, Valerie A., Thomas S., Said Ali, Le Vallee, Jean-Charles and Chen, H. (1998). Agricultural Market Performance and Determinants of Fertilizer Use in Ethiopia. Food Security Research Project Working Paper-10. Machigan State University (MSU), East Lansing.

Desai, D.K. (1986). Report on fertilizer use. Indian Journal of Agricultural Economics, 41(3): 418-423.

Eric A. Davidson. (2009). The contribution of manure and fertilizer nitrogen to atmospheric nitrous oxide since 1860 . Nature Geoscience, 2: $659-662$.

Fufa, B. and Hassan, R.M. (2006). Determinants of fertilizer use on maize in Eastern Ethiopia: A weighted endogenous sampling analysis of the extent and intensity of adoption. Agrekon, Vol 45, No 1 March 2006.

Gangadharan, T.P. (1980). Impact of credit on the use of modern farm inputs. 
Agriculture and Agro-Industries Journal, 13(3): 15-18.

Gregory J. DeAngelo and Batabyal, Amitrajeet A. (2004). A dynamic and stochastic analysis of fertilizer use in Swidden agriculture. Economics Bulletin, Vol. 17, No. 3, pp. 1-10.

Kaushik, Vijay Kumar and Paharia, N.C. (2014). Pattern of fertilizer use on major crops grown in Hisar district of Haryana. International Journal of Current Microbiology and Applied Sciences. 3(7): 665-672.

Kulkarni, K.R. (1980). Scope for increasing production of important oilseed crops under rainfed conditions through use of fertilizers and its economics. Fertilizer News, 25(10):26.

Kumar, P. (1986). Marketing problems of small and marginal farmers in India. Division of Agriculture Economics, IARI, New Delhi.

Kundhavi, K. (1986). Selling to consumer needs-an analysis of fertilizer retail outlets in Tamil Nadu. Fertilizer Marketing News, 17(9): 1-3.

Malik, R. S., Ramkal, Dahiya, R.R., Narwal, R.P. and Grewal, K.S. (2009). Assessment of fertilizer use impact on soil and water pollution in Haryana. Environment and Ecology 2009, Vol.27, 3A pp. 1426-1429.

Marrit Van Denberg. (2002). Environment and Development Economics. Environment and Development Economics, 7: 487-506.

Marwaha, P.S. and Gaur, O.P. (1993). Decontrolling of phosphatic and potassic fertilizers-likely impact on nutrient use. Indian Cooperative Review. 30(4): 382-388.

Mehra, H.K. (1999). Bringing business approach to farming by reorienting market development strategy. Fertilizer News, 44(9): 21-26.
Minot Nicholas, Mylene Kherallah and Philippe Berry (2000). Fertilizer market reform and the determinants of fertilizer use in Benin and Malawi. MSSD discussion paper No. 40, Markets and Structural Studies Division, International Food Policy Research Institute, 2033 K Street, N.W., Washington, U.S.A.

Mwangi, W., (1996). Low Use of Fertilizers and Low Productivity in Sub-Saharan Africa. NRG Paper 96-05. Mexico, D.F.: CIMMYT

Shyam, R. (1995). Impact of increase in fertilizer prices on consumption and cropping pattern. Adhoc Study Agro Economic Research Centre University of Allahabad, 94: 71.

Singh, R.D. (1995). Advertising and sales promotion under total fertilizer decontrolled scenario. Fertilizer News, 40(9): 55-61.

Subbarao, K. (1983). Institutions, infrastructure and regional variations in India's input delivery system. Proc. International Workshop on Agricultural Markets in the Semi-arid tropics. ICRISAT, India, 1985.

Sule, S.R., Rahane, R.K. and Kamble, V.S. (2002). Factors influencing use of biofertilizers. J. Maharashtra Agriculture University, 27 (1): 75-76.

Sundararaman, V. (1986). Block delivery scheme. Fertilizer News, 31(8): 30-31.

Tandon, H.L.S. (1981). Fertilizer use in dryland agriculture. European Nitrogen Service Programme. 22pp. From ESCAP Region Regional Information Support Service.

Tandon, H.L.S. (1993). Implications of present fertilizer policies on nutrient balance, soil health and yield sustainability in India. Fertilizer News. 38(12): 71-77.

Wallace Michael B. and Knausenberger Walter I. (1997). Inorganic Fertilizer 
Use in Africa: Environmental and Economic Dimensions, Applied Research, Technical Assistance and Training. Winrock International Environmental Alliance Arlington, Virginia, U.S.A.
Yanggen, David, Kelly, Valerie A., Reardon, Thomas and Naseem, Anwar. (1998). Incentives for Fertilizer Use in SubSaharan Africa: A Review of Empirical Evidence on Fertilizer Response and Profitability. International Development Paper. 70.

\section{How to cite this article:}

Vijay Kumar, Ishwar Dutt and Reetu Devi. 2018. Fertilizer Use Pattern on Major Crops Grown in Karnal District of Haryana. Int.J.Curr.Microbiol.App.Sci. 7(10): 2217-2224. doi: https://doi.org/10.20546/ijcmas.2018.710.254 